medRxiv preprint doi: https://doi.org/10.1101/2020.09.02.20186874; this version posted June 25, 2021. The copyright holder for this preprint (which was not certified by peer review) is the author/funder, who has granted medRxiv a license to display the preprint in perpetuity.

It is made available under a CC-BY-NC-ND 4.0 International license .

\title{
Modelling the impact of travel restrictions on COVID-19 cases in Newfoundland and Labrador
}

\author{
Amy Hurford ${ }^{1,2, *}$, Proton Rahman ${ }^{3}$, J. Concepción Loredo-Osti ${ }^{2}$ \\ ${ }^{1}$ Biology Department, Memorial University, St. John's NL A1B 3X9, Canada \\ ${ }^{2}$ Department of Mathematics and Statistics, Memorial University, St. John's NL A1B 3X9, Canada \\ ${ }^{3}$ Faculty of Medicine, Memorial University, St. John's, NL A1C 5B8, Canada \\ *Corresponding author: ahurford@mun.ca
}

Declaration of authors competing interests:

All authors are members of the Predictive Analytics team assembled by the Newfoundland and Labrador Center for Health Information to provide mathematical modelling support to the province of Newfoundland and Labrador. This manuscript arises from a technical report that was prepared at the request of the Department of Justice and Public Safety, Newfoundland and Labrador. This study was not influenced by any representatives of the province of Newfoundland and Labrador.

\section{Funding:}

$\mathrm{AH}$ was supported by a Discovery Grant from the National Sciences and Engineering Research Council of Canada.

Keywords: COVID-19; travel restrictions; Newfoundland and Labrador; importations; epidemic model; branching process 
medRxiv preprint doi: https://doi.org/10.1101/2020.09.02.20186874; this version posted June 25, 2021. The copyright holder for this preprint (which was not certified by peer review) is the author/funder, who has granted medRxiv a license to display the preprint in perpetuity. It is made available under a CC-BY-NC-ND 4.0 International license .

\begin{abstract}
In many jurisdictions, public health authorities have implemented travel restrictions to reduce coronavirus disease 2019 (COVID-19) spread. Policies that restrict travel within countries have been implemented, but the impact of these restrictions is not well known. On May $4^{\text {th }}, 2020$,

Newfoundland and Labrador (NL) implemented travel restrictions such that non-residents required exemptions to enter the province. We fit a stochastic epidemic model to data describing the number of active COVID-19 cases in NL from March $14^{\text {th }}$ to June $26^{\text {th }}$. We predicted possible outbreaks over 9 weeks, with and without the travel restrictions, and for contact rates $40 \%$ to $70 \%$ of pre-pandemic levels. Our results suggest that the travel restrictions reduced the mean number of clinical COVID-19 cases in NL by $92 \%$. Furthermore, without the travel restrictions there is a substantial risk of very large outbreaks. Using epidemic modelling, we show how the NL COVID-19 outbreak could have unfolded had the travel restrictions not been implemented. Both physical distancing and travel restrictions affect the local dynamics of the epidemic. Our modelling shows that the travel restrictions are a plausible reason for the few reported COVID-19 cases in NL after May $4^{\text {th }}$.
\end{abstract}

\title{
Background
}

In response to the COVID-19 pandemic, travel restrictions have frequently been implemented (Studdert, Hall, and Mello 2020), yet the efficacy of these restrictions has not been established. Some previous studies consider the impact of international travel restrictions (Chinazzi et al. 2020; Wells et al. 2020; Grépin et al. 2021; Russell et al. 2021), but there is a paucity of studies considering restricted travel within a nation (Grépin et al. 2021) making the implementation of travel restrictions controversial for public health authorities (Studdert, Hall, and Mello 2020). Furthermore, the impact of travel restrictions on reducing COVID-19 spread is interwoven with the impacts of other public health measures. For example, the spread of imported cases depends on compliance with selfisolation directives for travellers, local physical distancing, and mask wearing. Travel restrictions were implemented in Newfoundland and Labrador (NL) on May $4^{\text {th }}, 2020$, such that only NL residents and exempted individuals were permitted to enter the province. We use a mathematical model to consider a "what-if" scenario: specifically, "what if there were no travel-restrictions?", and in doing so, we quantify the impact that the travel restrictions had on the number of subsequent COVID-19 cases in NL.

Mathematical models appropriate for large populations will poorly predict the epidemic dynamics of smaller populations since chance events may dramatically alter an epidemic trajectory when there are only a few cases to begin with (Keeling and Rohani 2008). As such, it is not clear that results describing the impacts of international travel restrictions will also apply within countries, to smaller regions, and to regions with low infection prevalence. Imported infections due to the arrival of infected travellers will have a disproportionately large effect when the number of local cases is few (Russell et al., 2021). To appropriately characterize the impact of the travel restrictions on the COVID-19 outbreak in NL, we use a stochastic mathematical model appropriate for modelling infection dynamics in small populations (Keeling and Rohani 2008), and where a similar modelling approach has been used in other jurisdictions (Plank et al. 2020; Hellewell et al. 2020). Our analysis quantifies the impact of 
medRxiv preprint doi: https://doi.org/10.1101/2020.09.02.20186874; this version posted June 25, 2021. The copyright holder for this preprint (which was not certified by peer review) is the author/funder, who has granted medRxiv a license to display the preprint in perpetuity. It is made available under a CC-BY-NC-ND 4.0 International license .

travel restrictions by considering a higher rate of imported infections when there are no travel restrictions, and we use the model to predict the number of cases that could have occurred in NL in the 9 weeks subsequent to May $4^{\text {th }}$.

\section{Methods}

\section{Model overview}

Our model is based on Plank and colleagues (2020) who use a stochastic branching process to model COVID-19 dynamics in New Zealand. Our model describes the epidemiological dynamics of COVID-19 such that NL residents are either susceptible to, infected with, or recovered from COVID-19. Infected individuals are further divided into symptomatic and asymptomatic infections (infectious, no symptoms for the entire infectious period), and individuals with symptomatic infections may be in either the pre-clinical stage (infectious, prior to the onset of symptoms), or the clinical stage (infectious and symptomatic). The categorization of individuals into these infection classes is consistent with previous work (Hellewell et al. 2020; Davies et al. 2020).

Our model assumes that COVID-19 infections may spread when an infectious person contacts a susceptible person. Contact rates when physical distancing is undertaken in response to the pandemic are expressed in relative terms, as percentages of the contact rate relative to pre-pandemic levels. We assume that the pre-pandemic contact rate was equivalent to a basic reproduction number of $R_{0}=2.4$, where the definition of $R_{0}$ for our model is explained in Table 1 . Our model assumes that infected travelers that fail to self-isolate enter the population and may infect susceptible NL residents, and the rate of contact between residents and travellers is assumed to be the same as between residents. For individuals that are infectious (those with asymptomatic, pre-clinical and clinical infections), the probability of infection given a contact depends on the number of days since the date of infection (Ferretti et al. 2020), and infectivity further depends on whether the infection is preclinical, clinical or asymptomatic (Davies et al. 2020). Individuals with clinical infections are relatively less infectious because these individuals are symptomatic and are more likely to self-isolate.

Similar to models developed by other researchers, our model is formulated as a continuous time branching process (Arino et al. 2020; Hellewell et al. 2020; Plank et al. 2020). A branching process is a type of stochastic model where on any given simulation run, the predicted epidemic may be different since the epidemiological events, and the timing of these events, take values drawn from probability distributions. For example, our model assumes that the number of new infections generated by an infectious person follows a conditional Poisson distribution with a mean that depends on physical distancing, the number of susceptible individuals in the population, the type of infection the infected individual has (asymptomatic, pre-clinical, or clinical), and the number of days since the date of infection (see equation 1 in the Electronic Supplementary Material - ESM). Most other aspects of our model, for example, the timing of new infections, are similarly stochastic, each described by probability distributions that have appropriate characteristics, and are fully described in the ESM. An overview of the model and all parameter values are given in Figure 1 and Table 1.

Our model does not consider age-structure or contact rates between individuals in the population that vary in space and time, due to, for example, attending school or work. This latter model limitation is discussed in the Discussion section. We intentionally limit the complexity of our model, since when additional parameters are added to a model the uncertainty in the predictions builds up, 
medRxiv preprint doi: https://doi.org/10.1101/2020.09.02.20186874; this version posted June 25, 2021. The copyright holder for this preprint (which was not certified by peer review) is the author/funder, who has granted medRxiv a license to display the preprint in perpetuity. It is made available under a CC-BY-NC-ND 4.0 International license .

potentially to the point where the predictions may become useless (Saltelli et al. 2020). The model is implemented in $\mathrm{R}$ and the code is publically available at

https://doi.org/10.6084/m9.figshare.12906710.v2.

\section{Travel restriction scenarios}

We assumed that the rate that infected individuals enter NL after May $4^{\text {th }}$, and fail to self-isolate, is Poisson-distributed with a mean, $z_{1}=3$ (no travel restrictions) and $z_{2}=0.24$ per month (with travel restrictions). The assumed mean rate with travel restrictions yields model predictions compatible with the reported number of cases of COVID-19 in NL after May $4^{\text {th }}$ (see Figure 2). These parameter values, $\mathrm{z}_{1}$ and $\mathrm{z}_{2}$, imply that with the travel restrictions the number of infected travellers arriving in NL and failing to self-isolate is reduced by $92 \%$; or equivalently, without the travel restrictions the number of infected travellers arriving in NL and failing to self-isolate is 12.5 times greater. The mean rates that infected travellers enter $\mathrm{NL}$ and fail to self-isolate $\left(\mathrm{z}_{1}\right.$ and $\left.\mathrm{z}_{2}\right)$ are compound parameters consisting of three components: (i) the rate that travellers enter NL; (ii) the proportion of travellers that are infected; and (iii) the proportion of infected travellers that fail to self-isolate. We do not resolve the individual contributions of these three components to $z_{1}$ and $z_{2}$, however we note that only (i), the rate that travellers enter $\mathrm{NL}$, likely changes when travel restrictions are in place. We assumed that infected travellers may be asymptomatic or pre-clinical, as symptomatic travellers are assumed to self-isolate. The proportion of infections that are asymptomatic is assumed to be the same for both travellers and NL residents. The mean rate that infected travellers enter NL is assumed to be constant over time and the origin cities of the travellers is not considered.

\section{Epidemiological data and public health measures}

From March $14^{\text {th }}$ to June $26^{\text {th }}, 2020$, the government of NL reported the number of active COVID-19 cases during media updates and on the Newfoundland and Labrador Pandemic Update Data Hub (for the relevant data, see also Berry et al. 2020). A copy of the data that was used for our analysis is archived with our code (Hurford, Rahman, and Loredo-Osti 2020). In addition to the travel restrictions enacted on May $4^{\text {th }}$, legislation and public health recommendations that would have affected both the importation rate of COVID-19 to NL, and the spread of infections in the community are summarized in Table 2 . We assumed that the contact rate between NL residents changed after March 18,2020 , when a public health emergency was declared in NL.

\section{Model calibration}

We assumed that prior to March 18, 2020, the pre-pandemic basic reproduction number was $R_{0}=2.4$, where the assumed value of $R_{0}$ affects how quickly the epidemic would grow. All model parameters except the contact rate from March $19^{\text {th }}$ to May $4^{\text {th }}, \mathrm{c}_{1}$, were estimated independently of the NL COVID-19 case data (see Table 1). The contact rate, $c_{1}$, is expressed as a percentage relative to the pre-pandemic contact rate (as implied by the pre-pandemic $R_{0}$ assuming all other contributors to $R_{0}$ are fixed). To fit $\mathrm{c}_{1}$ given the data, we assumed that all clinical cases were reported, which is a reasonable assumption given the low number of cases reported in NL (for a model that considers unreported cases, see Liu et al. 2020). We estimated $c_{1}$ by observing that $c_{1}=30 \%$ resulted in an agreement of the model with the epidemic data (further details of the model calibration are provided in the ESM).

\section{Output variables}


medRxiv preprint doi: https://doi.org/10.1101/2020.09.02.20186874; this version posted June 25, 2021. The copyright holder for this preprint (which was not certified by peer review) is the author/funder, who has granted medRxiv a license to display the preprint in perpetuity. It is made available under a CC-BY-NC-ND 4.0 International license .

To determine the impact of travel restrictions, we characterize clinical infections occurring in NL after May $4^{\text {th }}$ as:

- Prior: the infected individual is part of an infection chain (i.e., a description of who infected whom) that originates from an NL resident infected prior to May $4^{\text {th }}$.

- Travel: the infected individual was infected prior to travelling to NL.

- Local: the infected individual is an NL resident, who did not travel outside the province, and is part of an infection chain that originates from a traveller to NL.

The number of clinical cases that are 'travel-related' is calculated as the sum of infections characterized as 'travel' and 'local'. The predicted number of COVID-19 cases refers only to clinical infections, and does not include asymptomatic infections.

\section{Results}

The predicted number of active clinical COVID-19 cases in NL from March $14^{\text {th }}$ to May $4^{\text {th }}$ (Figure 2, lines) broadly agrees with the data describing the number of active COVID-19 cases in NL over this same period (Figure 2, black dots). From May $4^{\text {th }}$ to June 26, 2020, when the travel restrictions were implemented in NL, the NL COVID-19 case data (Figure 2a, black dots) agrees with the model predictions for physical distancing scenarios corresponding to contact rates $\leq 60 \%$ of the prepandemic level (Figure 2a; coral - 40\%, khaki - 50\%, and green - 60\% lines).

We estimated that with the travel restrictions in place, from May $4^{\text {th }}$ to June $26^{\text {th }}, 2020$ the mean number of COVID-19 cases is reduced by $92 \%$ (Table 3). For the different physical distancing scenarios considered, the mean number of cases over the 9 weeks ranged from 14-48 clinical cases (without the travel restrictions), as compared to 1-4 clinical cases (with the travel restrictions; Table 3 and Figure 3a). These model predictions with the travel restrictions in place are consistent with the COVID-19 data for NL for the 9 weeks following May $4^{\text {th }}$ where during this time 2 new cases of COVID-19 were reported.

Without the travel restrictions, the number of clinical cases during the 9 weeks can be very large (Table 3 and Figure 3a). Specifically, for a contact rate at $60 \%$ of its pre-pandemic level, the upper limit on the 95\% prediction interval for the number of clinical cases over the 9 weeks is 79 (without the travel restrictions) and 17 (with the travel restrictions; Table 3, Figure 3a). The impact of the travel restrictions is even more substantial when only travel-related cases are considered (Figure 3b) since almost all infections arising when the travel restrictions are implemented are attributed to infection chains that arise from an NL resident infected prior to May $4^{\text {th }}$. The mean number of cases of each infection type: 'prior', 'travel' and 'local' are shown in Figure 4.

\section{Discussion}

Our model predictions broadly agree with the data describing the number of active COVID-19 cases in NL reported from March $14^{\text {th }}$ to May $4^{\text {th }}$, and from May $4^{\text {th }}$ to June $26^{\text {th }}$ if contract rates are $60 \%$ or less relative to pre-pandemic levels (Figure 2). Our modelling shows that implementing the travel restrictions on May $4^{\text {th }}$ reduced the number of COVID-19 cases by $92 \%$ over the subsequent 9 weeks 
medRxiv preprint doi: https://doi.org/10.1101/2020.09.02.20186874; this version posted June 25, 2021. The copyright holder for this preprint (which was not certified by peer review) is the author/funder, who has granted medRxiv a license to display the preprint in perpetuity. It is made available under a CC-BY-NC-ND 4.0 International license .

(Table 3). Furthermore, without the travel restrictions, large outbreaks are much more likely (Table 3 - 95\% prediction intervals; Figure 3a). Travel restrictions alone may be insufficient to limit COVID-19 spread since the level of physical distancing undertaken by the local community, which affects the contact rates between residents, is also a strong determinant of the outbreak size (Figures 2-4).

We found that the decrease in the mean number of clinical infections when the travel restrictions were enacted (a 92\% reduction; see Table 3) was nearly exactly equal to the reduction in travel due to the travel restrictions (a 92\% reduction; see Table 1). This equivalency was expected due to the hypothesized linear relationship between the importation rate and the mean outbreak size as noted in Anderson et al. 2020. A consequence of this linear relationship is that any relative changes in the mean outbreak size are expected to be equal to the relative changes in the importation rate (with travel restrictions relative to without restrictions and visa versa). The assumptions and characteristics of our model that give rise to this linear relationship are discussed in Table 4 along with examples of conditions where these assumptions would be violated.

Related research, using North American airline passenger data from January 1, 2019 to March 31, 2020, in combination with epidemic modelling, found that depending on the type of travel restrictions, the effective reproduction number, and the percentage of travellers quarantined, it would take between 37 and 128 days for $0.1 \%$ of the NL population to have been infected (Table 2 in Linka et al. 2020). These predicted epidemic trajectories are consistent with our results. However, unlike Linka et al. 2020, we have modelled importations and the NL epidemic dynamics as a stochastic process due to the low infection prevalence in NL at the time of our study.

\section{Future directions}

Our model does not consider spatial structure such that individuals contact each other in schools, workplaces, or 'bubbles'. The absence of spatial structure in our model may over-estimate the probability of an epidemic establishing and the total number of cases until the outbreak subsides (Keeling 1999). Related research, however, does consider spatially structured interactions in workplaces, businesses and schools, and concludes that without the travel restrictions implemented in NL on May $4^{\text {th }}$ the number COVID-19 cases would have been 10 times greater (Aleman et al., 2021) which is in close agreement with our results that the number of cases would have been 12.5 times greater (Table 3): a result that arises due to our parameterization of the importation rate without travel restrictions as 12.5 times greater than with travel restrictions (Tables 1 and 4). Travel restrictions are one of several approaches available to health authorities for COVID-19 management. Future research should consider the role of travel restrictions, testing, contact tracing and physical distancing, as elements of comprehensive approach to the best management of COVID-19.

\section{Limitations}

We were not able to estimate the rate that infected travellers enter $\mathrm{NL}$, however other research modelling infection dynamics in the origin cities of air travellers to NL found that without travel restrictions a new COVID-19 case would enter NL every other day (Linka et al. 2020). Similarly, we were not able to estimate the percentage of travellers to NL that comply with self-isolation directives. Smith et al. (2020) found that $75 \%$ of survey participants reporting COVID-19 symptoms (high temperature and/or cough) also report having left their house in the last 24 hours, violating the lockdown measures in place in the UK at the time, and so non-compliance rates may be quite high. Our analysis does not consider hospitalizations or deaths, however, we note that as of May $4^{\text {th }}, 2020$, 
medRxiv preprint doi: https://doi.org/10.1101/2020.09.02.20186874; this version posted June 25, 2021. The copyright holder for this preprint (which was not certified by peer review) is the author/funder, who has granted medRxiv a license to display the preprint in perpetuity. It is made available under a CC-BY-NC-ND 4.0 International license .

NL had experienced 259 clinical cases and 3 deaths. With the contact rate at $80 \%$ of its pre-pandemic level and no travel restrictions, we estimate that it would take, on average, 10.2 weeks for a further 259 clinical cases to occur, and although there is evidence that case fatality rates have changed over time (Ledford 2020), it is reasonable to expect a further 3 deaths under these conditions. In contrast, with the travel restrictions in place, it would take more than 6 months ( 28.1 weeks) for this same number of cases and deaths to accumulate. Thus, with the first COVID-19 vaccines available to the public a year after the beginning of the pandemic, the value of enacting travel restrictions to delay the local outbreak by 6 months is potentially substantial.

\section{Conclusion}

At the time of the implementation of the travel restrictions, there were few COVID-19 infections in NL. Without the travel restrictions, most of the subsequent COVID-19 infections would have been initiated by infected travellers who failed to comply with self-isolation requirements and only the actions of NL residents (i.e., physical distancing), and local health authorities (i.e., testing and contact tracing) would be sufficient to slow the exponential growth of these infection chains in the local community.

\section{References}

A foundation for living with COVID-19. Government of Newfoundland and Labrador. https://www.gov.nl.ca/covid-19/files/A-Foundation-for-Living-with-COVID-19.pdf

Aleman, Dionne, M., Benjamin Z. Tham, Sean J. Wagner, et al. 2021. How effective was Newfoundland and Labrador's travel ban to prevent the spread of COVID-19? An agent-based analysis. MedRxiv, https://www.medrxiv.org/content/10.1101/2021.02.05.21251157v3

Anderson, Sean C., Nicola Mulberry, Andrew M. Edwards, Jessica E. Stockdale, Sarafa A. Iyaniwura, Rebeca C. Falcao, Michael C. Otterstatter, Naveed Z. Janjua, Daniel Coombs, and Caroline Colijn. 2020. "How Much Leeway Is There to Relax COVID-19 Control Measures?" MedRxiv, June, 2020.06.12.20129833. https://doi.org/10.1101/2020.06.12.20129833.

Arino, Julien, Nicolas Bajeux, Stephanie Portet, and James Watmough. 2020. "Assessing the Risk of COVID-19 Importation and the Effect of Quarantine." MedRxiv, August, 2020.08.12.20173658. https://doi.org/10.1101/2020.08.12.20173658.

Atlantic Provinces form Travel Bubble. 2020. News Release, June 24. Executive Council. Government of Newfoundland and Labrador. https://www.gov.nl.ca/releases/2020/exec/0624n03/

Berry, Isha, Jean-Paul R. Soucy, Ashleigh Tuite, and David Fisman. 2020. Open access epidemiological data and an interactive dashboard to monitor the COVID-19 outbreak in Canada. CMAJ 192(15) E420.

Byambasuren, Oyungerel, Magnolia Cardona, Katy Bell, Justin Clark, Mary-Louise McLaws, and Paul Glasziou. 2020. "Estimating the Extent of Asymptomatic COVID-19 and Its Potential for Community Transmission: Systematic Review and Meta-Analysis." Official Journal of the Association of Medical Microbiology and Infectious Disease Canada, October, Accepted version, e20200030. https://doi.org/10.3138/jammi-2020-0030.

Chinazzi, Matteo, Jessica T. Davis, Marco Ajelli, Corrado Gioannini, Maria Litvinova, Stefano Merler, Ana Pastore y Piontti, et al. 2020. "The Effect of Travel Restrictions on the Spread of the 2019 Novel Coronavirus (COVID-19) Outbreak." Science 368 (6489): 395-400. https://doi.org/10.1126/science.aba9757. 
medRxiv preprint doi: https://doi.org/10.1101/2020.09.02.20186874; this version posted June 25, 2021. The copyright holder for this preprint (which was not certified by peer review) is the author/funder, who has granted medRxiv a license to display the preprint in perpetuity. It is made available under a CC-BY-NC-ND 4.0 International license .

Davies, Nicholas G., Adam J. Kucharski, Rosalind M. Eggo, Amy Gimma, W. John Edmunds, Thibaut Jombart, Kathleen O'Reilly, et al. 2020. "Effects of Non-Pharmaceutical Interventions on COVID-19 Cases, Deaths, and Demand for Hospital Services in the UK: A Modelling Study." The Lancet Public Health 0 (0). https://doi.org/10.1016/S2468-2667(20)30133-X.

Ferretti, Luca, Chris Wymant, Michelle Kendall, Lele Zhao, Anel Nurtay, Lucie Abeler-Dörner, Michael Parker, David Bonsall, and Christophe Fraser. 2020. "Quantifying SARS-CoV-2 Transmission Suggests Epidemic Control with Digital Contact Tracing." Science 368 (6491). https://doi.org/10.1126/science.abb6936.

Gardner, Crispin. 2009. Stochastic Methods: A Handbook for the Natural and Social Sciences. Springer. Grépin Karen Ann, Tsi-Lok Ho, Zhihan Liu, Summer Marion, Julianne Piper, Catherine Z Worsnop, and Kelley Lee. 2021. Evidence of the effectiveness of travel-related measures during the early phase of the COVID-19 pandemic. BMJ Global Health 6: e004537. doi:10.1136/bmjgh-2020004537

Gushue, John. 2020. "Crisis, What Crisis? If Canada Is in a 2nd COVID Wave, N.L. Is Watching It from Afar | CBC News." CBC. September 26, 2020. https://www.cbc.ca/news/canada/newfoundland-labrador/weekend-briefing-pandemicprovinces-1.5738454.

Hellewell, Joel, Sam Abbott, Amy Gimma, Nikos I. Bosse, Christopher I. Jarvis, Timothy W. Russell, James D. Munday, et al. 2020. "Feasibility of Controlling COVID-19 Outbreaks by Isolation of Cases and Contacts." The Lancet Global Health 8 (4): e488-96. https://doi.org/10.1016/S2214109X(20)30074-7.

Hurford, Amy, Proton Rahman, and J. Concepcion Loredo-Osti. 2020. "Modelling the Impact of Travel Restrictions on COVID-19 Cases in Newfoundland and Labrador." 2020.

https://doi.org/10.6084/m9.figshare.12906710.v2.

Keeling, M J. 1999. "The Effects of Local Spatial Structure on Epidemiological Invasions." Proceedings of the Royal Society B: Biological Sciences 266 (1421): 859-67.

Keeling, Matt, and Pejman Rohani. 2008. "Stochastic Dynamics." In Modeling Infectious Diseases in Humans and Animals. Princeton University Press.

Ledford, Heidi. 2020. “Why Do COVID Death Rates Seem to Be Falling?” Nature 587 (7833): 190-92. https://doi.org/10.1038/d41586-020-03132-4.

Liu, Zhihua, Pierre Magal, Ousmane Seydi, and Glenn Webb. 2020. Understanding unreported cases in the COVID-19 epidemic outbreak in Wuhan, China, and the importance of major public health interventions. Biology 9(3): 50.

Linka, Kevin, Proton Rahman, Alain Goriely, and Ellen Kuhl. 2020. "Is It Safe to Lift COVID-19 Travel Bans? The Newfoundland Story." Computational Mechanics. https://doi.org/10.1007/s00466020-01899-x.

Manhire, Toby. 2020. "New Modelling Reveals the Impact of Lockdown, and the Hopes for Elimination." The Spinoff (blog). April 9, 2020. https://thespinoff.co.nz/science/09-042020/new-modelling-reveals-the-impact-of-lockdown-and-the-hopes-for-elimination/. Nogrady, Bianca. 2020. "What the Data Say about Asymptomatic COVID Infections." Nature 587 (7835): 534-35. https://doi.org/10.1038/d41586-020-03141-3.

Newfoundland and Labrador Pandemic Update Data Hub. Government of Newfoundland and Labrador. https://covid-19-newfoundland-and-labrador-gnl.hub.arcgis.com/

North American COVID-19 Policy Response Monitor: Newfoundland and Labrador. North American Observatory on Health Systems and Policy. https://ihpme.utoronto.ca/wpcontent/uploads/2020/07/NL-COVID19-Response-Monitor 20200617b.pdf. 
medRxiv preprint doi: https://doi.org/10.1101/2020.09.02.20186874; this version posted June 25, 2021. The copyright holder for this preprint (which was not certified by peer review) is the author/funder, who has granted medRxiv a license to display the preprint in perpetuity. It is made available under a CC-BY-NC-ND 4.0 International license .

Plank, Michael J., Rachelle N. Binny, Shaun C. Hendy, Audrey Lustig, Alex James, and Nicholas Steyn. 2020. "A Stochastic Model for COVID-19 Spread and the Effects of Alert Level 4 in Aotearoa New Zealand." MedRxiv, April, 2020.04.08.20058743. https://doi.org/10.1101/2020.04.08.20058743.

Russell, Timothy W., Joseph, T. Wu, Sam Clifford, et al. 2021. Effect of internationally imported cases on internal spread of COVID-19: a mathematical modelling study. The Lancet Public Health 6(1): E12-E20.

Saltelli, Andrea, Gabriele Bammer, Isabelle Bruno, Erica Charters, Monica Di Fiore, Emmanuel Didier, Wendy Nelson Espeland, et al. 2020. "Five Ways to Ensure That Models Serve Society: A Manifesto." Nature 582 (7813): 482-84. https://doi.org/10.1038/d41586-020-01812-9.

Statistics Canada. 2017. “Focus on Geography Series, 2016 Cen-Sus.” Statistics Canada Catalogue no. 98-404-X2016001.

Studdert, David M., Mark A. Hall, and Michelle M. Mello. 2020. "Partitioning the Curve - Interstate Travel Restrictions During the Covid-19 Pandemic." New England Journal of Medicine 0 (0): null. https://doi.org/10.1056/NEJMp2024274.

Wells, Chad R., Pratha Sah, Seyed M. Moghadas, Abhishek Pandey, Affan Shoukat, Yaning Wang, Zheng Wang, Lauren A. Meyers, Burton H. Singer, and Alison P. Galvani. 2020. "Impact of International Travel and Border Control Measures on the Global Spread of the Novel 2019 Coronavirus Outbreak." Proceedings of the National Academy of Sciences 117 (13): 7504-9. https://doi.org/10.1073/pnas.2002616117.

Table 1. Parameter values

\begin{tabular}{|c|c|c|}
\hline Quantity & Description & Source \\
\hline \multicolumn{3}{|c|}{ Fixed } \\
\hline$N_{\text {pop }}=523,000$ & NL population size & $\begin{array}{l}\text { Estimated as } \\
519,716 \text { in } 2016 \text { (Statistics Canada } \\
2017 \text { ) }\end{array}$ \\
\hline$\pi=0.15$ & $\begin{array}{l}\text { Proportion of infections that are } \\
\text { asymptomatic }\end{array}$ & $\begin{array}{l}\text { Estimated as } 17 \% \text { in Byambasuren et al. } \\
\text { (2020). Known to take a wide range of } \\
\text { values (Saltelli et al. 2020; Nogrady } \\
2020)\end{array}$ \\
\hline$\eta_{s}=0.25$ & $\begin{array}{l}\text { Proportion reduction in infectivity for } \\
\text { asymptomatic infections relative to } \\
\text { clinical infections }\end{array}$ & Davies et al. 2020 \\
\hline$c_{\text {iso }}=0.5$ & $\begin{array}{l}\text { Proportion reduction in infectivity for } \\
\text { individuals with clinical infections due to } \\
\text { self-isolation. }\end{array}$ & Davies et al. 2020 \\
\hline$R_{0}=2.4$ & $\begin{array}{l}\text { The pre-pandemic basic reproduction } \\
\text { number. This is the number of secondary } \\
\text { infections generated by an individual } \\
\text { with a pre-clinical infection over their } \\
\text { entire infectivity period, when all } \\
\text { individuals in the population are } \\
\text { susceptible. For our model, the } \\
\text { definition of Ro supposes that the level } \\
\text { of infectivity corresponding to a pre- }\end{array}$ & Assumed \\
\hline
\end{tabular}


medRxiv preprint doi: https://doi.org/10.1101/2020.09.02.20186874; this version posted June 25, 2021. The copyright holder for this preprint (which was not certified by peer review) is the author/funder, who has granted medRxiv a license to display the preprint in perpetuity.

It is made available under a CC-BY-NC-ND 4.0 International license .

\begin{tabular}{|c|c|c|}
\hline & $\begin{array}{l}\text { clinical infection is retained for the } \\
\text { entire duration of the infectivity period } \\
\text { (see equation } 1 \text { in the ESM). Note that a } \\
\text { change in } R_{0} \text { relative to its pre-pandemic } \\
\text { level is equal to the same change in the } \\
\text { contact rate if all other contributors to } \\
R_{0} \text { (i.e., the recovery rate and the } \\
\text { probability of infection given a contact) } \\
\text { are assumed unchanged. }\end{array}$ & \\
\hline$c_{1}=30 \%$ & $\begin{array}{l}\text { Contact rate after March } 18^{\text {th }}, 2020 \text {, } \\
\text { expressed as a percentage of the pre- } \\
\text { pandemic contact rate. }\end{array}$ & $\begin{array}{l}\text { Estimated from NL COVID-19 case data } \\
\text { (see Figure 2) }\end{array}$ \\
\hline $\begin{array}{l}c_{2} \text { in }[40 \%, \\
70 \%]\end{array}$ & $\begin{array}{l}\text { Contact rate after May } 4^{\text {th }}, 2020 \text {, } \\
\text { expressed as a percentage of the pre- } \\
\text { pandemic contact rate. }\end{array}$ & Range considered \\
\hline \multicolumn{3}{|c|}{ Sampled } \\
\hline$W(2.83,5.67)$ & $\begin{array}{l}\text { Infectivity, which depends on the } \\
\text { number of days since the date of } \\
\text { infection (Weibull-distributed). }\end{array}$ & Ferretti et al. 2020 \\
\hline$s \sim \Gamma(6.1,1.7)$ & $\begin{array}{l}\text { The time from date of infection to self- } \\
\text { isolation (gamma-distributed). }\end{array}$ & $\begin{array}{l}\text { Plank et al. 2020. Note that } s \approx T_{1}+T_{2} \text {, } \\
\text { where } T_{1} \text { and } T_{2} \text { appear in Plank et al. } \\
2020 .\end{array}$ \\
\hline $\begin{array}{l}\mathrm{Z}_{1} \sim \\
\mathrm{POIS}(0.008)\end{array}$ & $\begin{array}{l}\text { The number of imported infected } \\
\text { individuals per month that fail to self- } \\
\text { isolate when travel restrictions are in } \\
\text { place after May } 4^{\text {th }} \text { (Poisson-distributed). } \\
\text { The mean value is } 0.24 \text { infected } \\
\text { travellers per month that fail to self- } \\
\text { isolate. }\end{array}$ & $\begin{array}{l}\text { Fit to NL COVID-19 case data when } c_{2} \leq \\
60 \% \text { (see Figure } 2 \text { ) }\end{array}$ \\
\hline $\mathrm{z}_{2} \mathrm{POIS}(0.1)$ & $\begin{array}{l}\text { The number of imported infected } \\
\text { individuals per month that fail to self- } \\
\text { isolate when there are no travel } \\
\text { restrictions after May } 4^{\text {th }} \text { (Poisson- } \\
\text { distributed). The mean value is } 3 \\
\text { infected travellers per month that fail to } \\
\text { self-isolate. }\end{array}$ & $\begin{array}{l}\text { The mean importation rate is reduced } \\
\text { by } 92 \% \text { when travel restrictions are in } \\
\text { place since } z_{1}=(1-0.92) z_{2} \text {. Therefore, } \\
\text { the } z_{2} \text { value is consistent with data } \\
\text { reporting a } 92.2 \% \text { decrease in the } \\
\text { number of passengers arriving at St. } \\
\text { John's airport }(\mathrm{NL}) \text { in June } 2020 \text { relative } \\
\text { to June } 2019(\mathrm{Gushue} 2020) \text {. } \\
\text { Equivalently, this assumption can be } \\
\text { stated as that without travel restrictions } \\
\text { the importation rate is } 12.5 \text { times } \\
\text { greater }(=0.1 / 0.008) \text {. }\end{array}$ \\
\hline
\end{tabular}

Table 2. Public health measures implemented in Newfoundland and Labrador, March 6 - July 3, 2020 
medRxiv preprint doi: https://doi.org/10.1101/2020.09.02.20186874; this version posted June 25, 2021. The copyright holder for this preprint (which was not certified by peer review) is the author/funder, who has granted medRxiv a license to display the preprint in perpetuity.

It is made available under a CC-BY-NC-ND 4.0 International license .

\begin{tabular}{|c|c|}
\hline \multicolumn{2}{|c|}{ Measures affecting the importation rate } \\
\hline $\begin{array}{l}\text { March } \\
20,2020\end{array}$ & $\begin{array}{l}\text { All individuals arriving from outside NL must self-isolate for } 14 \text { days } \\
\text { (North American COVID-19 Policy Response Monitor: Newfoundland } \\
\text { and Labrador, 2020) }\end{array}$ \\
\hline $\begin{array}{l}\text { May 4, } \\
2020\end{array}$ & $\begin{array}{l}\text { - All individuals are prohibited from entering NL except: } \\
\text { a. Residents of NL } \\
\text { b. Asymptomatic workers and individuals subject to the } \\
\text { Exemption Order. } \\
\text { c. Individuals who have been permitted entry to NL, due to } \\
\text { extenuating circumstances, approved in advance by the } \\
\text { Chief Medical Officer of Health. } \\
\text { - Individuals arriving from outside NL must self-isolate for } 14 \text { days, } \\
\text { be available for contact by public health, and complete a travel } \\
\text { declaration form at the point of entry. (Special Measures Order - } \\
\text { Travel, May 15, 2020). }\end{array}$ \\
\hline $\begin{array}{l}\text { July } 3, \\
2020\end{array}$ & $\begin{array}{l}\text { Atlantic bubble: Interprovincial travel without the requirement to self- } \\
\text { isolate permitted in Newfoundland and Labrador, New Brunswick, } \\
\text { Prince Edward Island and Nova Scotia, for residents of Atlantic Canada } \\
\text { (Atlantic Provinces form Travel Bubble, 2020). }\end{array}$ \\
\hline \multicolumn{2}{|c|}{ Measures affecting community spread } \\
\hline $\begin{array}{l}\text { March } \\
6,2020\end{array}$ & $\begin{array}{l}\text { Any resident with symptoms asked to stay at home and complete the } \\
\text { self assessment tool (North American COVID-19 Policy Response } \\
\text { Monitor: Newfoundland and Labrador, 2020). }\end{array}$ \\
\hline $\begin{array}{l}\text { March } \\
18,2020\end{array}$ & $\begin{array}{l}\text { Alert level } 5 * \text {. State of emergency declared. Residents advised to } \\
\text { practice physical distancing and only leave their homes for essential } \\
\text { purposes. Only essential businesses open. Gatherings of more than } 50 \\
\text { prohibited. Restaurants are takeout only. (Public Health Promotion and } \\
\text { Protection Act; *inferred as alert levels not yet defined) }\end{array}$ \\
\hline $\begin{array}{l}\text { March } \\
30,2020\end{array}$ & $\begin{array}{l}\text { Gatherings of more than } 5 \text { prohibited (North American COVID-19 Policy } \\
\text { Response Monitor: Newfoundland and Labrador, 2020). }\end{array}$ \\
\hline $\begin{array}{l}\text { May 11, } \\
2020\end{array}$ & $\begin{array}{l}\text { Alert level } 4 \text { (see 'A foundation for living with COVID-19'). Households } \\
\text { are permitted to form 'double bubbles'. Gatherings of up to } 10 \text { people, } \\
\text { reopening of parks and certain businesses. Childcare services operating } \\
\text { at 50\% (North American COVID-19 Policy Response Monitor: } \\
\text { Newfoundland and Labrador, 2020). }\end{array}$ \\
\hline $\begin{array}{l}\text { May 29, } \\
2020\end{array}$ & $\begin{array}{l}\text { Six more people can be added to 'double bubbles' (North American } \\
\text { COVID-19 Policy Response Monitor: Newfoundland and Labrador, } \\
\text { 2020). }\end{array}$ \\
\hline $\begin{array}{l}\text { June 10, } \\
2020\end{array}$ & $\begin{array}{l}\text { Alert level 3. Gatherings of up to } 20 \text { people, responsible intra-provincial } \\
\text { travel, and medium-intensity sports permitted. Childcare services } \\
\text { operating at } 70 \% \text { (North American COVID-19 Policy Response Monitor: } \\
\text { Newfoundland and Labrador, 2020). }\end{array}$ \\
\hline $\begin{array}{l}\text { June } 25 \text {, } \\
2020\end{array}$ & $\begin{array}{l}\text { Alert level 2. Occupancy and gatherings limited to } 50 \text { people, with } \\
\text { physical distancing (including funerals, weddings, burials, indoor pools, } \\
\text { gyms, movie theatres, bowling alleys, etc). Wakes, karaoke and dance }\end{array}$ \\
\hline
\end{tabular}


medRxiv preprint doi: https://doi.org/10.1101/2020.09.02.20186874; this version posted June 25, 2021. The copyright holder for this preprint (which was not certified by peer review) is the author/funder, who has granted medRxiv a license to display the preprint in perpetuity.

It is made available under a CC-BY-NC-ND 4.0 International license .

floors not allowed. Virtual delivery of health care encouraged. (Public Health Advisory June 24, 2020).

Table 3. Predicted total number of clinical COVID-19 cases in the 9 weeks subsequent to May $4^{\text {th }}$ with and without the implementation of travel restrictions. The prediction intervals represent the simulated 0.025 and 0.975 quantiles.

\begin{tabular}{|c|c|c|c|c|}
\hline \multirow{2}{*}{$\begin{array}{l}\text { Percentage reduction in } \\
\text { the contact rate relative } \\
\text { to pre-pandemic levels }\end{array}$} & \multicolumn{4}{|c|}{ Predicted clinical COVID-19 cases over 9 weeks } \\
\hline & $\begin{array}{l}\text { Travel } \\
\text { restrictions }\end{array}$ & $\begin{array}{l}\text { No travel } \\
\text { restrictions }\end{array}$ & $\begin{array}{l}\text { Magnitude } \\
\text { greater without } \\
\text { restrictions }\end{array}$ & $\begin{array}{l}\text { Percentage } \\
\text { reduction with } \\
\text { restrictions }\end{array}$ \\
\hline \multicolumn{5}{|l|}{$40 \%$} \\
\hline Mean & 1.2 & 13.6 & 11.0 & $91.2 \%$ \\
\hline Median & 0 & 12 & & \\
\hline 95\% prediction intervals & {$[0,9]$} & {$[2,35]$} & & \\
\hline \multicolumn{5}{|l|}{$50 \%$} \\
\hline Mean & 1.5 & 18.1 & 12.0 & $91.7 \%$ \\
\hline Median & 0 & 15 & & \\
\hline 95\% prediction intervals & {$[0,11]$} & {$[3,53]$} & & \\
\hline \multicolumn{5}{|l|}{$60 \%$} \\
\hline Mean & 2.1 & 27.8 & 13.5 & $92.4 \%$ \\
\hline Median & 0 & 23 & & \\
\hline 95\% prediction intervals & {$[0,17]$} & {$[3,79]$} & & \\
\hline \multicolumn{5}{|l|}{$70 \%$} \\
\hline Mean & 3.7 & 47.9 & 13.0 & $92.3 \%$ \\
\hline Median & 0 & 35 & & \\
\hline \multirow[t]{2}{*}{ 95\% prediction intervals } & {$[0,33]$} & {$[3,159]$} & & \\
\hline & & & Mean $=12.4$ & Mean $=91.9 \%$ \\
\hline
\end{tabular}

Table 4. A list of the assumptions and characteristics of our model that give rise to the linear relationship between the importation rate and the mean outbreak size. The linear relationship is that $I_{\text {tot }}=\lambda_{v} I_{1}$, where $I_{\text {tot }}$ is the mean total number of cases, $\lambda_{v}$ is the importation rate, and $I_{1}$ is the mean number of cases that arise from one importation.

\begin{tabular}{|l|l|l|}
\hline Model assumption & $\begin{array}{l}\text { Example where the model } \\
\text { assumption is violated }\end{array}$ & $\begin{array}{l}\text { Effect of violating the assumption on } \\
\text { outbreak size }\end{array}$ \\
\hline $\begin{array}{l}\text { Mixing between } \\
\text { individuals in the } \\
\text { population is } \\
\text { homogeneous. }\end{array}$ & $\begin{array}{l}\text { A group of travellers, all of } \\
\text { whom are infected, fail to } \\
\text { self-isolate, but also travel } \\
\text { everywhere together and }\end{array}$ & $\begin{array}{l}\text { No matter what the size of the group, } \\
\text { the resulting outbreak will be of similar } \\
\text { size since the contacts of group } \\
\text { members are redundant. Here, the }\end{array}$ \\
\hline
\end{tabular}


medRxiv preprint doi: https://doi.org/10.1101/2020.09.02.20186874; this version posted June 25, 2021. The copyright holder for this preprint (which was not certified by peer review) is the author/funder, who has granted medRxiv a license to display the preprint in perpetuity.

It is made available under a CC-BY-NC-ND 4.0 International license .

\begin{tabular}{|c|c|c|}
\hline $\begin{array}{l}\text { Homogeneous mixing } \\
\text { means than an infected } \\
\text { person is equally likely } \\
\text { to contact every } \\
\text { susceptible person in } \\
\text { the population. }\end{array}$ & $\begin{array}{l}\text { contact all of the same } \\
\text { people. } \\
\text { Mixing is non-homogeneous } \\
\text { because group members are } \\
\text { constrained to have contacts } \\
\text { only amongst the same } \\
\text { individuals as the other group } \\
\text { members, and not all } \\
\text { individuals in the population. }\end{array}$ & $\begin{array}{l}\text { mean outbreak size is not linearly } \\
\text { related to the importation rate because } \\
\text { a larger group would correspond to a } \\
\text { larger number of importations, yet the } \\
\text { resulting outbreak would not be much } \\
\text { larger. }\end{array}$ \\
\hline $\begin{array}{l}\text { The number of } \\
\text { susceptible people is } \\
\text { relatively unchanged } \\
\text { during the timeframe of } \\
\text { interest. }\end{array}$ & $\begin{array}{l}\text { The susceptible population is } \\
\text { small, or infection control } \\
\text { measures are few. }\end{array}$ & $\begin{array}{l}\text { Infected individuals that arrive later will } \\
\text { generate smaller infection chains due to } \\
\text { fewer susceptible people to infect. } \\
\text { Therefore, the total outbreak size } \\
\text { cannot be calculated by summing the } \\
\text { size of the outbreaks per importation, } \\
\text { since the timing of the importation } \\
\text { affects the outbreak size due to that } \\
\text { importation. }\end{array}$ \\
\hline $\begin{array}{l}\text { The number of people } \\
\text { an infected person } \\
\text { contacts is unchanged } \\
\text { during the timeframe of } \\
\text { interest. }\end{array}$ & $\begin{array}{l}\text { Waning compliance with } \\
\text { public health measures; } \\
\text { school re-openings. }\end{array}$ & $\begin{array}{l}\text { As above, outbreak sizes per } \\
\text { importation cannot be added to } \\
\text { determine the total outbreak size } \\
\text { because the timing of the importations } \\
\text { affects the value of the outbreak size per } \\
\text { importation. }\end{array}$ \\
\hline $\begin{array}{l}\text { Infectivity does not } \\
\text { change over time. }\end{array}$ & Seasonality & See above. \\
\hline Model characteristic & A different characteristic & $\begin{array}{l}\text { Effect of considering the different } \\
\text { characteristic }\end{array}$ \\
\hline $\begin{array}{l}\text { Few 'prior' cases: cases } \\
\text { that are not attributable } \\
\text { to importations (see } \\
\text { Methods - Output } \\
\text { variables). }\end{array}$ & $\begin{array}{l}\text { High infection prevalence in } \\
\text { absence of importations. }\end{array}$ & $\begin{array}{l}\text { The relationship between travel-related } \\
\text { cases and the importation rate will be } \\
\text { linear, but total infections is the sum of } \\
\text { prior cases and travel-related cases, } \\
\text { such that the linear relationship will not } \\
\text { hold. }\end{array}$ \\
\hline $\begin{array}{l}\text { The quantity of interest } \\
\text { is the mean outbreak } \\
\text { size. }\end{array}$ & $\begin{array}{l}\text { The quantity of interest is the } \\
\text { median or a different } \\
\text { quantile. }\end{array}$ & $\begin{array}{l}\text { The linear relationship with the } \\
\text { importation rate applies only to the } \\
\text { mean outbreak size. As can be observed } \\
\text { in Table } 2 \text {, the linear relationship does } \\
\text { not apply to the median or } 95 \% \\
\text { prediction intervals. }\end{array}$ \\
\hline
\end{tabular}


medRxiv preprint doi: https://doi.org/10.1101/2020.09.02.20186874; this version posted June 25, 2021. The copyright holder for this preprint (which was not certified by peer review) is the author/funder, who has granted medRxiv a license to display the preprint in perpetuity. It is made available under a CC-BY-NC-ND 4.0 International license.

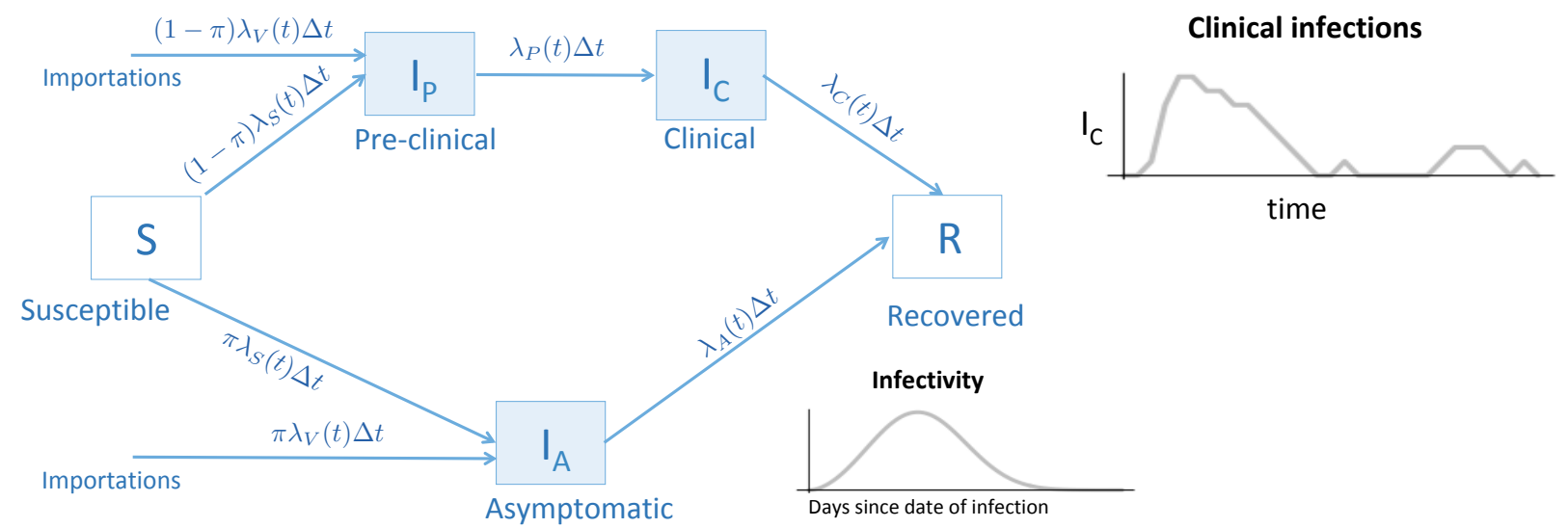

Figure 1. Model diagram. Uninfected individuals (white boxes) are either susceptible to infection, $\mathrm{S}$, or recovered, R. Susceptible individuals become infected at mean rate, $\lambda_{s}(t) \Delta t$, where the event that an infection occurs is sampled from a distribution since the model is stochastic. Recovered individuals cannot be re-infected. Infected travellers that fail to self-isolate enter the population at a mean rate, $\lambda_{V}(t) \Delta t$. When a new infection occurs, a proportion, $\pi$, of these newly infected individuals are asymptomatic, where the number of individuals with asymptomatic infections at any time is $I_{A}$. Alternatively, a proportion, $1-\pi$, of infected individuals will eventually develop clinical symptoms, although these individuals are initially pre-clinical (without symptoms), and the number of individuals that are pre-clinical at any time is I . At a mean rate, $\lambda_{P}(t) \Delta t$, individuals with pre-clinical infections develop clinical infections (with symptoms). Individuals with asymptomatic, pre-clinical, and clinical infections are infectious (blue boxes), and infectivity depends on the type of infection, and the number of days since the date of infection. Finally, both individuals with asymptomatic and clinical infections recover at mean rates $\lambda_{A}(t) \Delta t$ and $\lambda_{C}(t) \Delta t$, respectively. See the ESM for further details. 
medRxiv preprint doi: https://doi.org/10.1101/2020.09.02.20186874; this version posted June 25, 2021. The copyright holder for this preprint (which was not certified by peer review) is the author/funder, who has granted medRxiv a license to display the preprint in perpetuity.

It is made available under a CC-BY-NC-ND 4.0 International license .
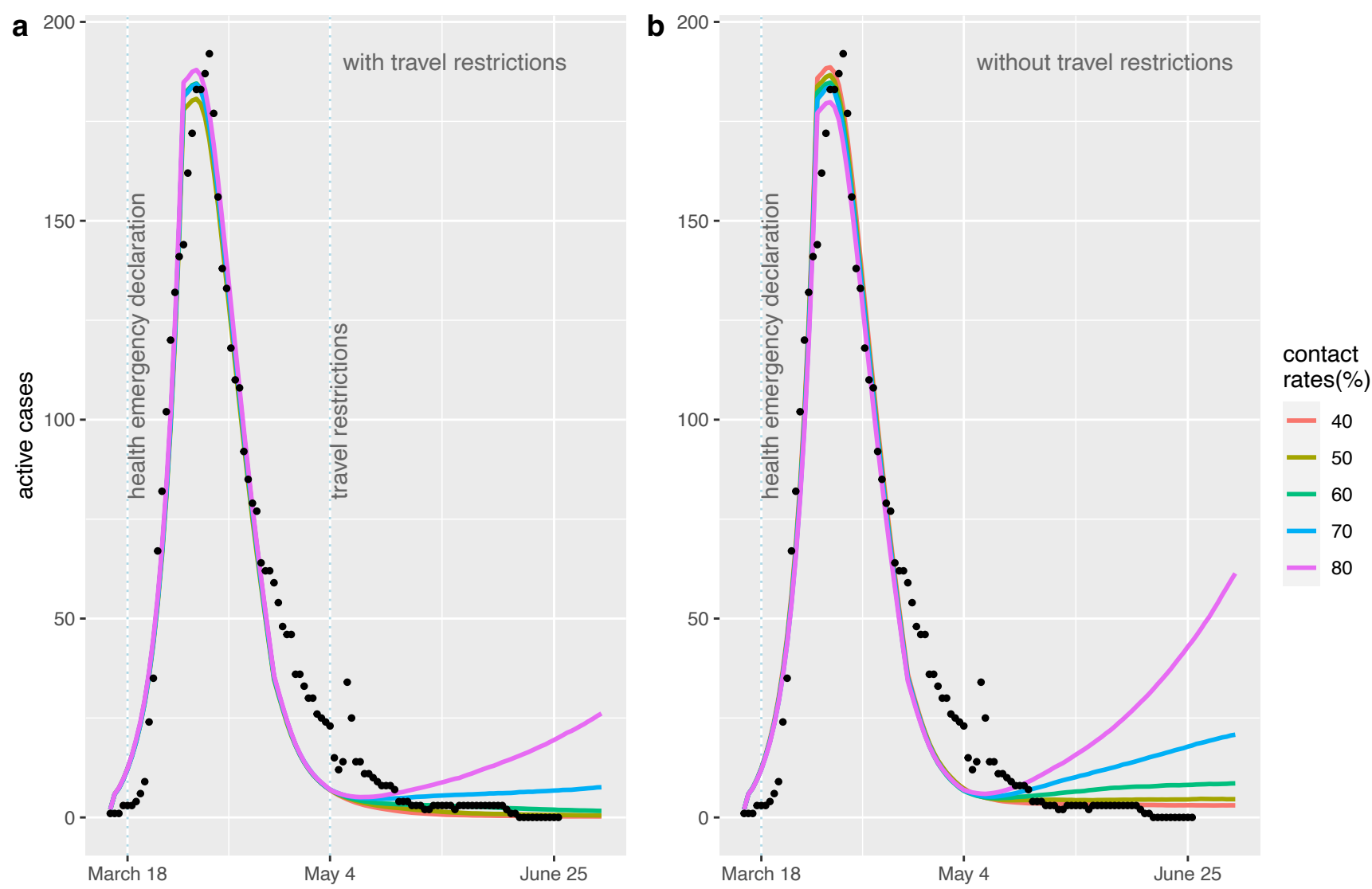

Figure 2. The predicted mean number of active COVID-19 cases (lines) agrees well with the reported numbers of active COVID-19 cases in NL from March $16^{\text {th }}$ to June $26^{\text {th }}$ (dots) prior to the implementation of the travel restrictions on May $4^{\text {th }}$. After May $4^{\text {th }}$, we consider an alternative past scenario where no travel restrictions were implemented (b). Both with (a) and without (b) the travel restrictions, we consider different levels of physical distancing, represented as percentages of the daily contact rate at the pre-pandemic level (coloured lines). Each coloured line is the mean number of active clinical cases each day calculated from 1000 runs of the stochastic model, which considers variability in the timing and changes in the number of individuals with different COVID-19 infection statuses. 
medRxiv preprint doi: https://doi.org/10.1101/2020.09.02.20186874; this version posted June 25, 2021. The copyright holder for this preprint (which was not certified by peer review) is the author/funder, who has granted medRxiv a license to display the preprint in perpetuity.

a

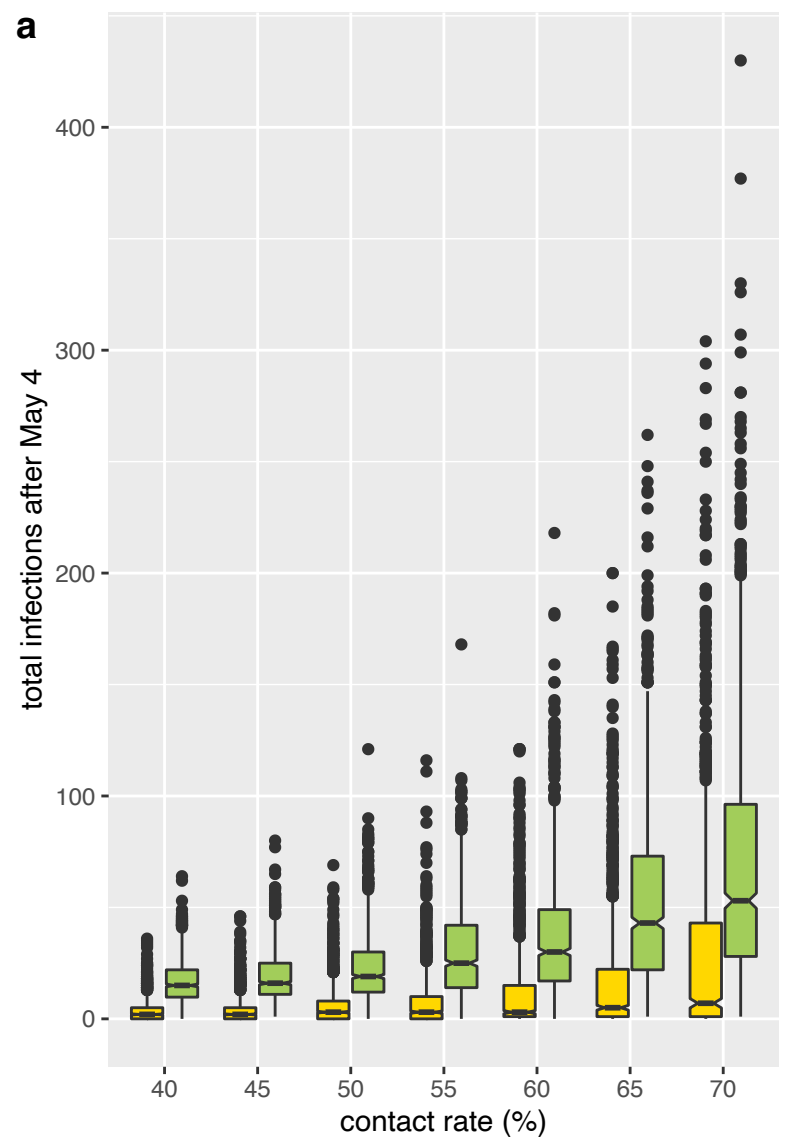

b
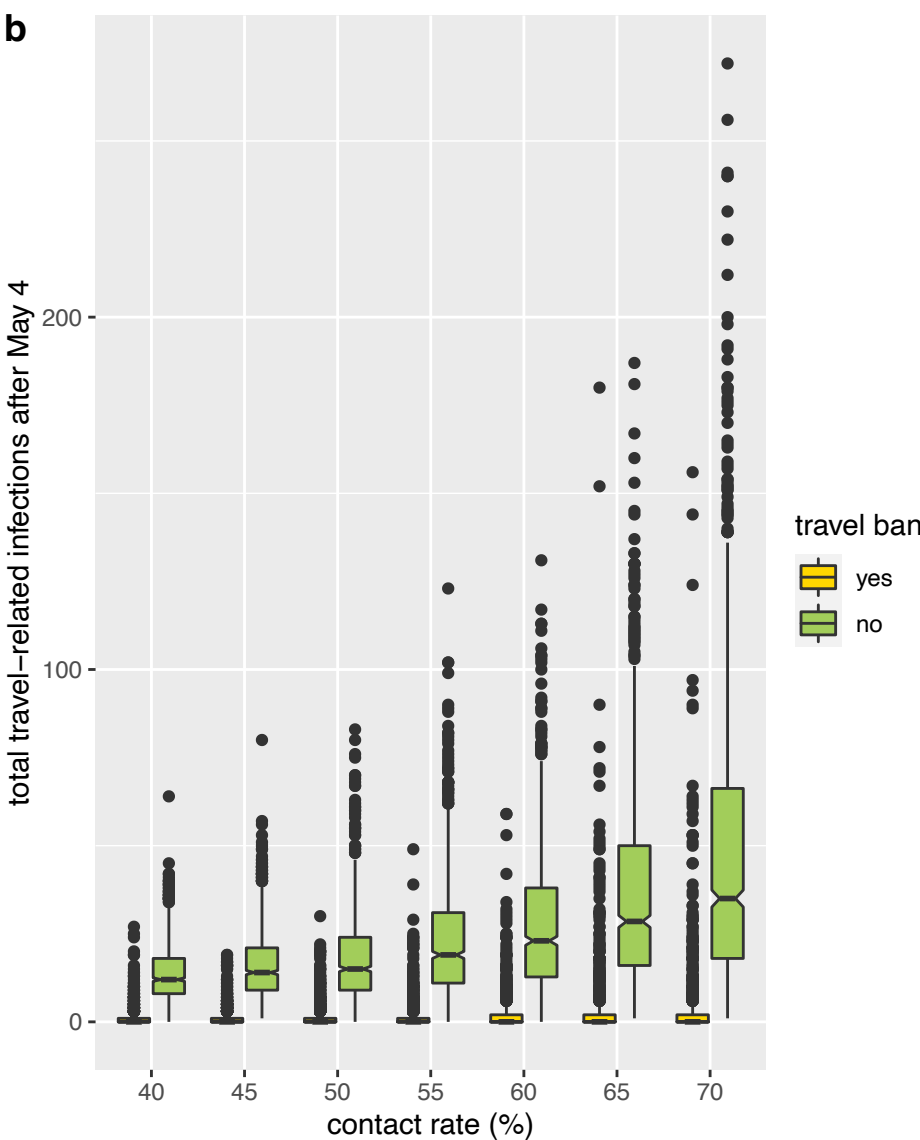

Figure 3. The total predicted number of COVID-19 cases in NL occurring over 9 weeks beginning on May $4^{\text {th }}$ when travel restrictions are implemented (yellow boxes) is much less than the total number of cases occurring over this same period if the travel restrictions were not implemented (green boxes). The total number of COVID-19 cases occurring during the 9 weeks subsequent to May $4^{\text {th }}$ is highly variable, and without the implementation of the travel restrictions there is a higher risk of a large outbreak (also see Table 3 - 95\% prediction intervals). When the travel restrictions are implemented, almost all of the cases occurring during the 9 weeks subsequent to May $4^{\text {th }}$ are due to infected individuals present in the community prior to May $4^{\text {th }}$. Travel-related cases are all cases remaining after the 'prior' cases are removed (b). The contact rate is expressed as a percentage of the pre-pandemic contact rate. For each simulation, chance events affect the number of individuals that change COVID-19 infection statuses and the timing of these changes. The horizontal lines are medians, the colored boxes are 1.58 times the interquartile range divided by the square root of $n$, the whiskers are $95 \%$ prediction intervals, and the dots are outliers for the $n=1000$ simulation outcomes. 
medRxiv preprint doi: https://doi.org/10.1101/2020.09.02.20186874; this version posted June 25, 2021. The copyright holder for this preprint (which was not certified by peer review) is the author/funder, who has granted medRxiv a license to display the preprint in perpetuity.

It is made available under a CC-BY-NC-ND 4.0 International license .

a

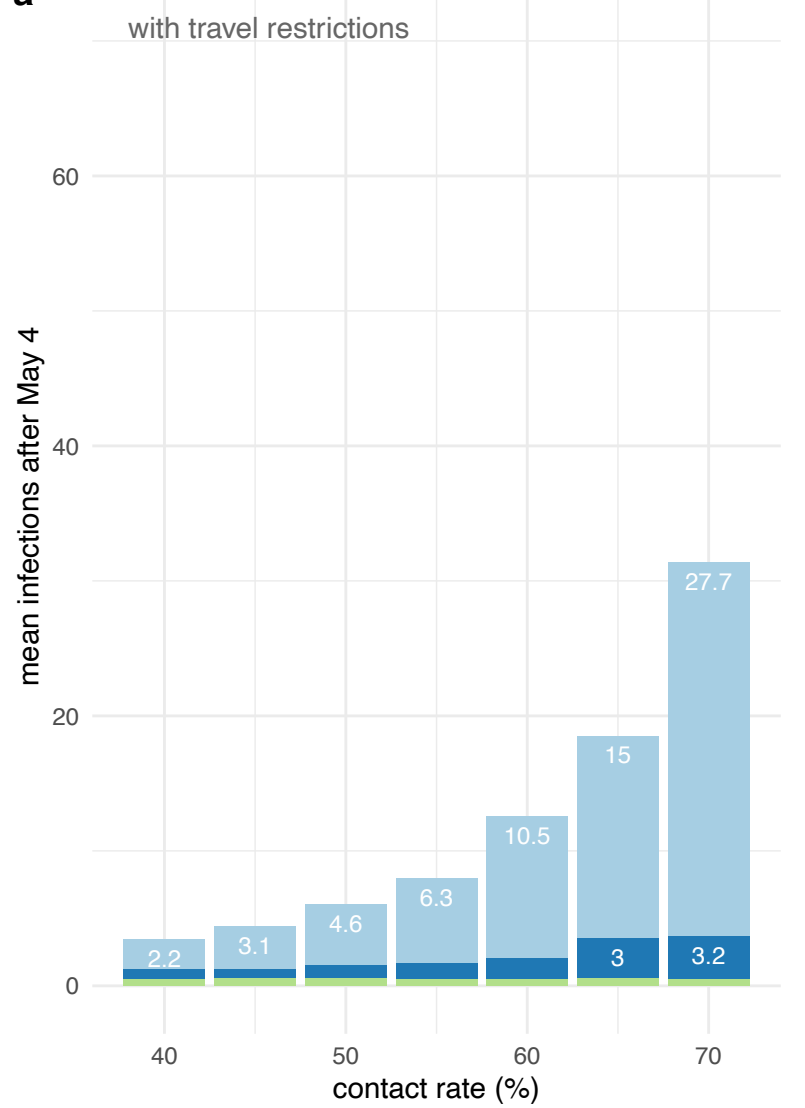

b

60

without travel restrictions

40

20

0

40

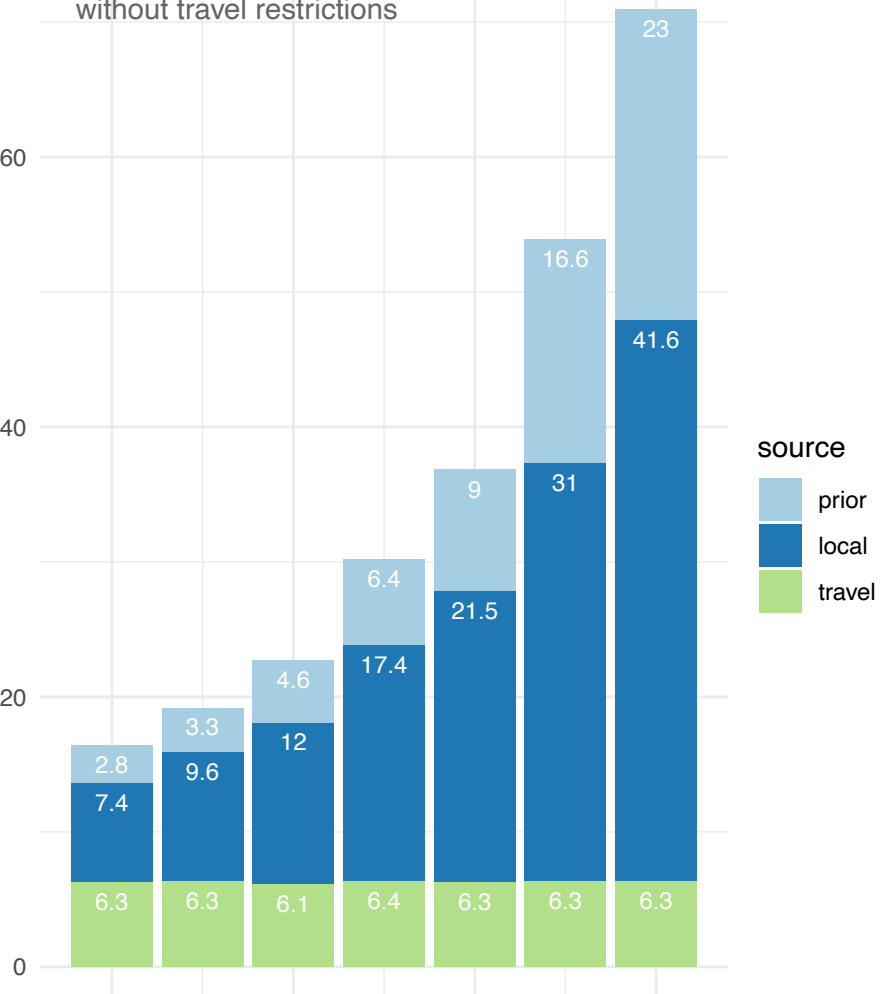

60

Figure 4. The breakdown into three different sources of COVID-19 cases occurring in NL over 9

weeks. We compare simulation results with travel restrictions (a) and without travel restrictions (b). The source of infections is either: an individual infected prior to May $4^{\text {th }}$ ('prior', light blue); an individual that was infected prior to entering NL ('travel', green); or a NL resident that did not travel, but is part of an infection chain where the initial infectee is a traveller that entered NL after May $4^{\text {th }}$ ('local', dark blue). Our model assumptions are reflected by the difference in the number of COVID-19 cases occurring in travellers over the 9 weeks (green bars): approximately 1.5 with travel restrictions (a), as compared to 6.3 without travel restrictions (b). These infected travellers seed infection chains in the NL community resulting in a larger number of NL residents infected when the travel restrictions are not implemented (dark blue bars). Both with and without the travel restrictions, the number of cases due to prior infection in the NL community is similar (light blue bars). The contact rate is expressed as a percentage of the pre-pandemic contact rate. 
medRxiv preprint doi: https://doi.org/10.1101/2020.09.02.20186874; this version posted June 25, 2021. The copyright holder for this preprint (which was not certified by peer review) is the author/funder, who has granted medRxiv a license to display the preprint in perpetuity. It is made available under a CC-BY-NC-ND 4.0 International license .

\section{Electronic Supplementary Material}

Modelling the impact of travel restrictions on COVID-19 cases in Newfoundland and Labrador Amy Hurford, Proton Rahman and J. Concepción Loredo-Osti

1. Model description

... page 1

2. Negative binomial distribution of secondary infections

... page 3

3. Model calibration

... page 4

\section{Model description}

1. Infected individuals either: (i) will show clinical symptoms at some point during their infection (with probability $1-\pi$ ), or (ii) will be asymptomatic (with probability $\pi$ ).

2. Individuals that are pre-clinical, clinical, or asymptomatic (see Figure 1) are all infectious with different levels of infectivity given contact with a susceptible person. The infectivity of infected individuals changes depending on the number of days since infection onset and follows a Weibull distribution that is parameterized such that peak infectivity occurs approximately 5 days after the initial infection, and $90 \%$ of infections occur between 2.0 and 8.4 days after the infection onset. It is also assumed that 21 days after infection onset an individual is no longer infective. See Ferretti et al. 2020 for a justification of this assumption.

3. Individuals with asymptomatic infections are less likely than pre-clinically infected individuals to infect a susceptible person given a contact, where $\eta_{s}$ is a coefficient that scales the infectivity of asymptomatic individuals relative to pre-clinically infected individuals.

4. Clinically infected individuals are assumed to self-isolate, which reduces their infectivity by a factor $\mathrm{c}_{\text {iso }}$ relative to individuals with pre-clinical infections.

5. Infected individuals that will progress to have a clinical infection have an initial period when they are pre-clinical, $T_{1}$. This distribution is the same as the distribution for the period from the date of infection to self-isolation, and is gamma-distributed, $s \sim \Gamma(6.1,1.7)$. Note that we let $s \approx$ $T_{1}+T_{2}$, where $T_{1}$ and $T_{2}$ appear in Plank et al. 2020.

6. Each infected individual $j$, per unit time, generates a Poisson-distributed number of new infections with a mean equal to $\lambda_{j}(t) \Delta t$. This mean number of secondary infections depends on the fraction of susceptible people in the population, $1-N(t) / N_{\text {pop }}$, the type of infection the infective person has, $\mathrm{F}_{\mathrm{j}}(\mathrm{t})$, the infectivity of the infected individual a given number of days since the date of infection, whether the infected person is in self-isolation, and the rate of contacts between individuals in the population.

The rate of infection for the $\mathrm{j}^{\text {th }}$ individual (infected at the time $t_{j}$ ) on the time interval $(t, t+\Delta t$ ] is $\lambda_{j}(t) \Delta t$, where

$$
\lambda_{j}(t)=R_{0}\left(1-\frac{N(t)}{N_{\text {pop }}}\right) C(t) F_{j}(t) \int_{0}^{\infty} d_{j}(t-\tau) f_{W}(\tau) d \tau
$$

and, 
medRxiv preprint doi: https://doi.org/10.1101/2020.09.02.20186874; this version posted June 25, 2021. The copyright holder for this preprint (which was not certified by peer review) is the author/funder, who has granted medRxiv a license to display the preprint in perpetuity.

It is made available under a CC-BY-NC-ND 4.0 International license .

$$
d_{j}(t)= \begin{cases}1 & \text { if the } j^{t h} \text { individual became infected in the interval }(t, t+\Delta t] \\ 0 & \text { otherwise }\end{cases}
$$

$f_{W}(\tau)$ is the density of the serial-interval time, $W$, and $F_{j}(t)$ and $C(t)$ are given by,

$$
F_{j}(t)= \begin{cases}1.00 & \text { if the } j^{t h} \text { individual is pre-symptomatic at the time } t \\ 0.50 & \text { if the } j^{t h} \text { individual is in isolation at time } t \\ 0.75 & \text { if the } j^{t h} \text { individual is infective-asymptomatic at the time } t\end{cases}
$$

and, $C(t)$, the function that accounts for public health measures is defined as,

$$
C(t)= \begin{cases}1 & \text { if } t<t_{1} \\ c_{1} & \text { if } t_{1} \leq t<t_{2} \\ c_{2} & \text { otherwise }\end{cases}
$$

where $t_{1}=$ March 18, 2020 is the date of the declaration of the health emergency in NL, and $t_{2}$ $=$ May 4, 2020, the date when we consider scenarios representing different contact rates between NL residents.

We performed additional simulations where the number of new infections followed a negative binomial distribution. Our results were strongly consistent with the simulations when the Poisson distribution was assumed (Figure A.3).

7. The time between an individual becoming infected and infecting another individual, the generation time, follows a Weibull distribution with a shape parameter equal to 2.83 and a scale parameter equal to 5.67 (mean value is 5 days). The infection times of all $\mathrm{N}_{\mathrm{j}}$ secondary infections from an individual $\mathrm{j}$ are independent identically distributed random variables from this distribution.

8. On an interval of length $\Delta t$, the rate that infected travellers arrive and fail to self-isolate is $\lambda_{V}(t) \Delta t$, which follows a Poisson distribution with the parameter $\lambda_{V}(t)$ given as,

$$
\lambda_{V}(t) \sim \begin{cases}0.1 & \text { if } t<t_{2} \\ 0.008 & \text { if } t \geq t_{2} \text { and } r=\text { restrictions } \\ 0.1 & \text { if } t \geq t_{2} \text { and } r=\text { no restrictions }\end{cases}
$$

where $r=$ restrictions corresponds to travel restrictions, $r=$ no restrictions corresponds to no travel restrictions, and $t_{2}$ corresponds to May 4, 2020.

The model is a stochastic birth-death process where births correspond to new infections and deaths correspond to the recovery of infected individuals. The counts arise from a non-homogeneous Poisson process, and the model describes a lagged process owing to the consideration of the serial interval distribution. The model is implemented in R using Euler's method (Gardner 2009).

\section{Definitions of the mean rates appearing in Figure 1}

Susceptible individuals become infected at a mean rate, $\lambda_{s}(t) \Delta t$, with $\lambda_{S}(t)=\Sigma_{j} \lambda_{j}(t)$ where $\lambda_{j}(t)$ is given by equation 1 . Infected travellers that fail to self-isolate enter the population at a rate $\lambda_{V}(t)$ (equation 
medRxiv preprint doi: https://doi.org/10.1101/2020.09.02.20186874; this version posted June 25, 2021. The copyright holder for this preprint (which was not certified by peer review) is the author/funder, who has granted medRxiv a license to display the preprint in perpetuity.

It is made available under a CC-BY-NC-ND 4.0 International license .

5). At a rate, $\lambda_{P}(t) \Delta t$, with $\lambda_{P}(t)=\Sigma_{j} \gamma_{j}^{P}(t)$ individuals with pre-clinical infections develop clinical infections. Finally, both individuals with asymptomatic and clinical infections recover at rates $\lambda_{A}(t) \Delta t$ with $\lambda_{A}(t)=\Sigma_{j} \gamma_{j}^{A}(t)$ and $\lambda_{C}(t) \Delta t$ with $\lambda_{C}(t)=\Sigma_{j} \gamma_{j}{ }^{C}(t)$, respectively. The probability of removing the $j^{\text {th }}$ individual from the $K$ class in the time interval $(t, t+\Delta t]$, given that this individual has not been removed before is,

$$
\gamma_{j}^{K}(t)=\int_{0}^{\infty} d_{j}(t-\tau) \frac{f_{K}(\tau)}{1-F_{K}(\tau)} d \tau \quad \text { for } K \in\{P, C, A\}
$$

where $f_{K}(\tau)$ and $F_{K}(\tau)$ are the density and distribution functions for the time to removal from the $K$ class

\section{Negative binomial distribution of secondary infections}

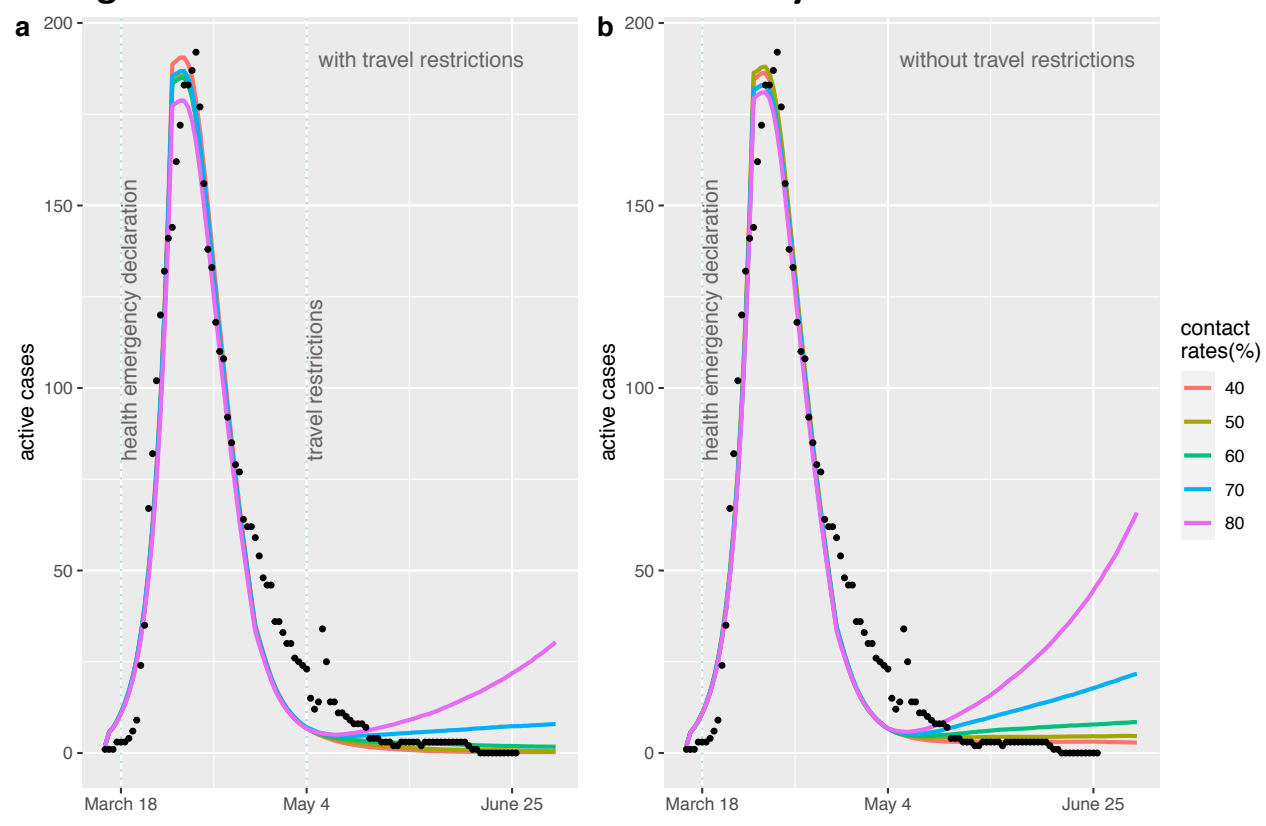

Figure A.1. We repeated our simulations assuming that the number of secondary infections followed a negative binomial distribution with $\mathrm{k}=0.1$ (Endo et al. 2020) rather than a Poisson distribution (see 6. of Model description in this Appendix). For the negative binomial distribution, we set $R_{0}=4.67$ so that the model predictions were consistent with the NL data from March $16^{\text {th }}$-June $26^{\text {th }}, 2020$, as shown in this figure. 
medRxiv preprint doi: https://doi.org/10.1101/2020.09.02.20186874; this version posted June 25, 2021. The copyright holder for this preprint (which was not certified by peer review) is the author/funder, who has granted medRxiv a license to display the preprint in perpetuity. It is made available under a CC-BY-NC-ND 4.0 International license .

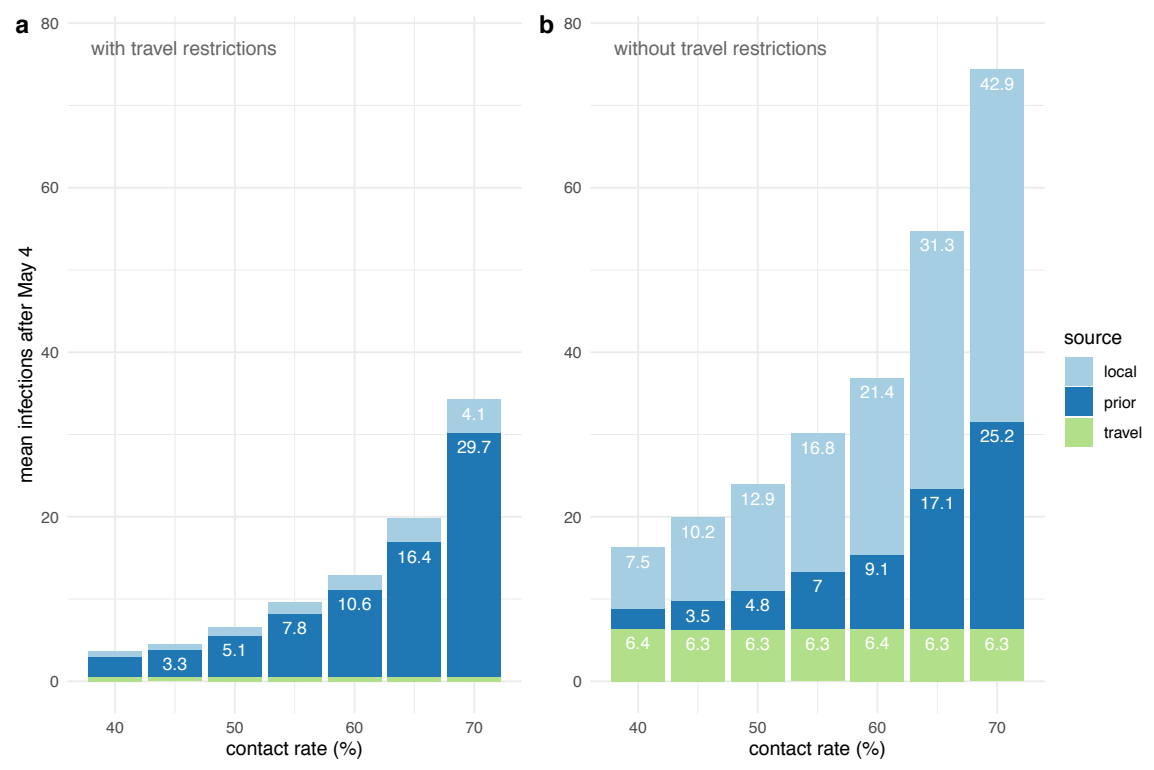

Figure A.2. We repeated our simulations assuming that the number of secondary infections followed a negative binomial distribution with $\mathrm{k}=0.1$ (Endo et al. 2020) rather than a Poisson distribution (see 6. of Model description in this Appendix). For the negative binomial distribution, we set $R_{0}=4.67$ so that the model predictions were consistent with the NL data from March $16^{\text {th }}$-June $26^{\text {th }}, 2020$ (Figure A.1). This figure is comparable to Figure 3, which assumed a Poisson distribution of secondary infections.

\section{Model Calibration}

We estimated the percentage of contacts between March 19 and May 4, 2020, relative to the prepandemic level as $c_{1}=30 \%$. To estimate $c_{1}$, we used model calibration, where different values of $c_{1}$ were considered and the resulting agreement with the data was observed. In Figure A.3, we show that when $c_{1}=20 \%$ (red) the peak number of active cases occurs too early, and the number of active cases during the decline is under-predicted. When $c_{1}=40 \%$ (Figure A.3, blue), the number of active cases before and after the peak is over-estimated. For our analysis, we used $c_{1}=30 \%$ (Figure A.3, green), as this value was consistent with the epidemic data (black dots). We did not consider a formal fitting algorithm due to the long computational times associated with fitting stochastic models, because we cannot precisely estimate the other model parameters, and because Figure A.3 demonstrates that the estimated $c_{1}$ value is likely between 20 and $40 \%$. 
medRxiv preprint doi: https://doi.org/10.1101/2020.09.02.20186874; this version posted June 25, 2021. The copyright holder for this preprint (which was not certified by peer review) is the author/funder, who has granted medRxiv a license to display the preprint in perpetuity.

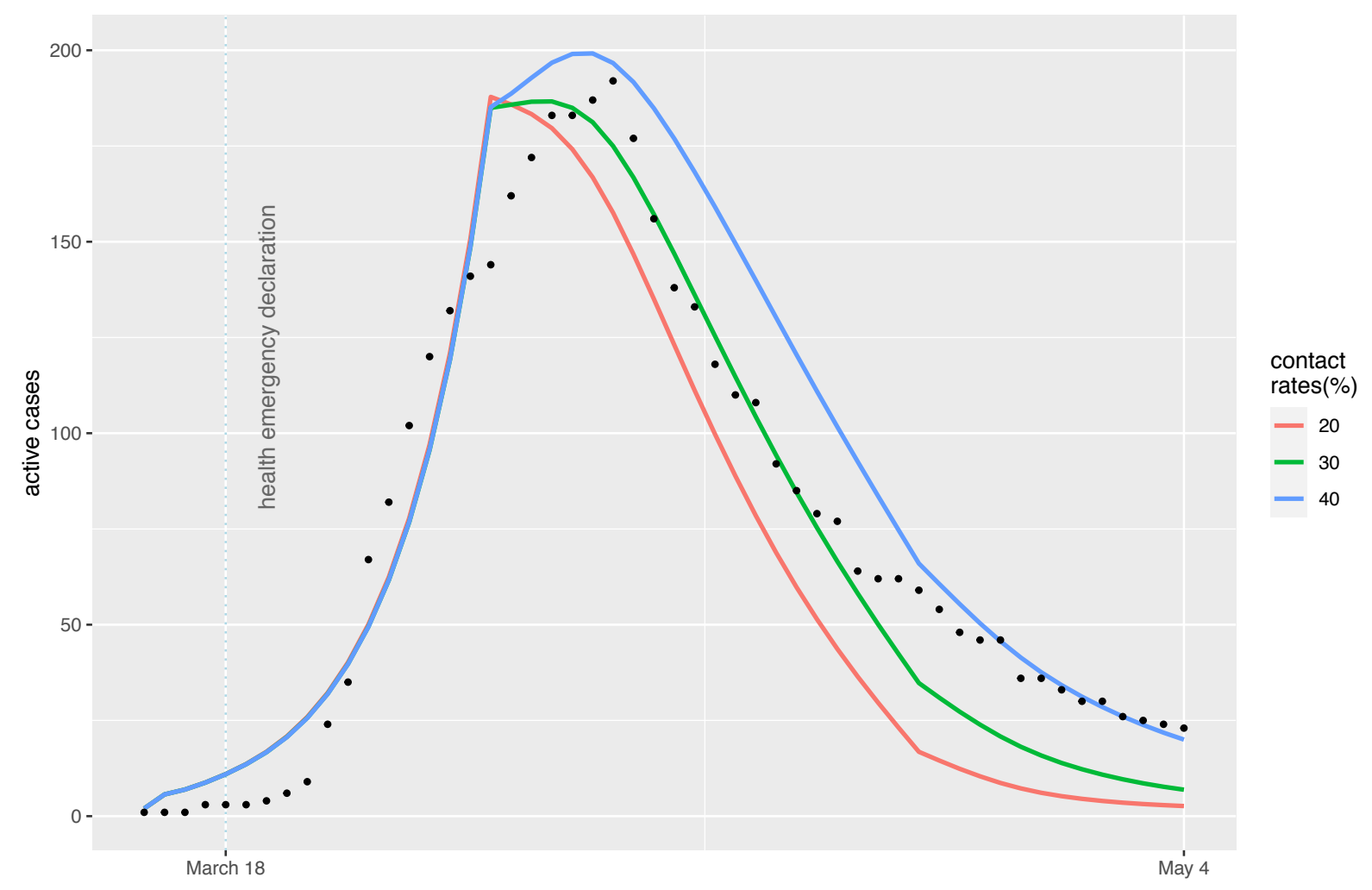

Figure A.3. Our analysis assumed the percentage of contacts between March 19 and May 4, 2020 relative to the pre-pandemic baseline was $c_{1}=30 \%$ (green line). This value was estimated using model calibration and observing the agreement of the model with the epidemic data (black dots). If $c_{1}=20 \%$ (red), the peak number of active cases occurs too early, and the number of active cases during the decline is under-predicted. If $c_{1}=40 \%$ (blue), the number of active cases before and after the peak is over-estimated.

\section{References}

Endo, Akira, Centre for the Mathematical Modelling of Infectious Diseases COVID-19 Working Group, Sam Abbott, Adam J. Kucharski, and Sebestian Funk. 2020. Estimating the overdispersion in COVID-19 transmission using outbreak sizes outside China. Welcome Open Research 5(67). Ferretti, Luca, Chris Wymant, Michelle Kendall, Lele Zhao, Anel Nurtay, Lucie Abeler-Dörner, Michael Parker, David Bonsall, and Christophe Fraser. 2020. "Quantifying SARS-CoV-2 Transmission Suggests Epidemic Control with Digital Contact Tracing." Science 368 (6491). https://doi.org/10.1126/science.abb6936.

Gardner, Crispin. 2009. Stochastic Methods: A Handbook for the Natural and Social Sciences. Springer. Plank, Michael J., Rachelle N. Binny, Shaun C. Hendy, Audrey Lustig, Alex James, and Nicholas Steyn. 2020. "A Stochastic Model for COVID-19 Spread and the Effects of Alert Level 4 in Aotearoa New Zealand." MedRxiv, April, 2020.04.08.20058743. 